\title{
EKOFISH : Program Edukasi Optimalisasi Pemanfaatan Ekosistem Mangrove Kepada Masyarakat Dusun Cemara, Lombok Barat
}

\author{
Nazar Amrullah ${ }^{1}$, Sulfah Rahmadiah², Bq Mia Rexa Liani ${ }^{3}$, Susi Susanti ${ }^{4}$, Sopian Efendi ${ }^{5}$
}

${ }^{1}$ Pendidikan Sosiologi/Jurusan IImu Pengetahuan Sosial FKIP Universitas Mataram

${ }^{2}$ Budidaya Perairan/Jurusan Perikanan dan Ilmu Kelautan FAPERTA Universitas Mataram

${ }^{3}$ Pendidikan Fisika/Jurusan MIPA FKIP Universitas Mataram

${ }^{4}$ Kehutanan/Jurusan Budidaya Pertanian FAPERTA Universitas Mataram

${ }^{5}$ Perpajakan/D3 Fakultas Ekonomi dan Bisis Universitas Mataram

${ }^{*}$ Co-Author :sulfahnuraga@gmail.com

\begin{abstract}
ABSTRAK. Berdasarkan hasil Survei Sosial Ekonomi Nasional (Susenas) oleh BPS, jumlah penduduk Inodonesia yang hidup di bawah garis kemiskinan tahun 2017 tercatat masih cukup besar yakni, sekitar 27,77 juta jiwa atau kurang lebih 10,64 persendari total jumlah penduduk. Salah satu kantong kemiskinan paling besar di Indonesia adalah wilayah sekitar pesisir, hampir 32, 14\% dari jumlah penduduk miskin total Indonesia (Direktur Pengembangan Usaha KKP, 2017). Dusun Cemara dapat dikategorikan sebagai daerah dengan kantong kemiskin struktual yang potensial. Keberadaan hutan bakau (managrove) dengan luasan skitar 66,41 Ha disekitar pesisir pantai merupakan potensi yang masih perlu dioptimalkan pemanfaatannya oleh masyarakat. Oleh karena itu perlu diadakan inovasi dalam pemberian edukasi atau pembekalan terhadap masyarakat setempat yang dikemas dalam program ekonomi kreatif berkelanjutan terkait sectorperikanan dan kelautan. Ekofish merupakan sebuah program pemberdayaan masyarakat Dusun Cemare dalam memanfaatkan potensi Eosistem Mangrove berbasis ekonomi kreatif dan digital marketing dengan dua teknik yaitu pengolahan hasil dari buah mangrove yang dijadikan panganan khas dan pembuatan tambak teknik Silvofishery yang dalam hal ini berpengaruh dalam kelangsungan hidup mangrove dan pelestariaanya untuk dimanfaatkan lebih lenjut. Dengan adanya program Ekofish ini diharapkan mampu membantu meningkatkan taraf hidup masyarakat setempat juga dapat membantu mewujudkan lestarinya mangrove di Desa Lembar Selatan.
\end{abstract}

Kata Kunci: Hutan Mangrove, Silvofishery, Ekonomi Kreatif,Ekofish.

ABSTRACT. Based on the results of the National Socio-Economic Survey (Susenas) by $B P S$, the total population of Inodonesia living below the poverty line in 2017 is still quite large, which is around 27.77 million people or approximately 10.64 percent of the total population. One of the biggest pockets of poverty in Indonesia is the area around the coast, almost 32, 14\% of the total Indonesian poor (Director of Business Development KKP, 2017). Dusun Cemara can be categorized as an area with a potential poor structural bag. The existence of mangrove forests (managrove) with an area of around 66.41 ha around the coast is a potential that still needs to be optimized by the community. Therefore, it is necessary to innovate in providing education or debriefing to local communities which are packaged in sustainable creative economic programs related to the fisheries and marine sector. Ekofish is an empowerment program of Cemare Hamlet community in utilizing the potential of a Mangrove Ecosystem based on creative economy and digital marketing with two techniques, namely processing of mangrove fruit which is used as a typical food and making Silvofishery engineering ponds which in this case affect the survival of mangrove and pelestaria more extended. With the existence of the Ekofish program, it is expected to be able to help improve the standard of living of the local community can also help realize the sustainability of mangroves in the village of Lembar Selatan.

Keyword: Mangrove Forests, Silvofishery, Creative Economy, Ekofish. 


\section{PENDAHULUAN}

Berdasarkan hasil Survei Sosial Ekonomi Nasional (Susenas) oleh BPS, jumlah penduduk Inodonesia yang hidup di bawah garis kemiskinan tahun 2017 tercatat masih cukup besar yakni, sekitar 27,77 juta jiwa atau kurang lebih 10,64 persen dari total jumlah penduduk. Salah satu kantong kemiskinan paling besar di Indonesia adalah wilayah sekitar pesisir, hampir 32, 14\% dari jumlah pensusuk miskin total Indonesia (Direktur Pengembangan Usaha KKP, 2017). Hal tersebut menjadi ironis mengingat potensi sumberdaya alam disekitar mereka tersedia relatif besar. Hasil susenas 2014 mengungkapkan bahwa kemiskinan terbesar berada pada masyarakat pesisir mencapai 178.000 orang tersebar di 236 desa pesisir dengan tingkat pendapatan rata-rata Rp. 3.850.000/kapita per tahun atau Rp 310.000/bulan. Apabila dikaitkan denganjumlah tanggungan keluarga rata-rata 4-5 orang, maka rumah tangga masyarakat pesisir tergolong kategori miskin.

Disamping itu, Ekosistem mangrove merupakan habitat bagi berbagai organism baik darat maupun laut (mamalia dan amphibi) seperti kepiting, udang, ikan, monyet dan lain sebagainya. Ekosistem hutan mangrove memiliki fungsi ekologis, ekonomis dan sosial yang penting dalam pembangunan, khususnya di wilayah pesisir (Paruntu, dkk., 2016). Beberapa fungsi dan manfaat hutan mangrove diantaranya adalah sebagai pelindung garis pantai, tempat berpijah aneka biota laut, sebagai pengatur iklim mikro, penghasil keperluan rumah tangga danin dustri, penghasil bibit ikan, sebagai bahan baku obat-obatan, pariwisata, penelitian dan pendidikan serta manfaatmanfaat yang lainnya (Hidayatullah, 2013).

Dusun Cemara merupakan salah satu dusun di Kecamatan lembar, Lombok Barat yang masuk dalam wilayah pesisr dengan jumlah penduduk lebih dari 1000 jiwa. Berdasarkan keadaan ekonominya, Dusun Cemara dapat dikategorikan sebagai daerah dengan kantong kemiskin struktual yang potensial. Keberadaan hutan bakau (managrove) dengan luasan skitar 66,41 Ha disekitar pesisir pantai merupakan potensi yang masih perlu dioptialkan pemanfaatannya oleh masyarakat. Sejauh ini pemanfaatan mangrove di Dusun Cemara hanya sebagai dareah Ekowisata dan Pematang tambak nelayan. Padahal, jika ditelisik lebih jauh kebermanfaatan hutan mangrove dapat dimanfaatkan lebih dari itu, baik dari segi ekonomi maupul Lingkungn.

Ekofish yang merupakan kepajangan dari Economic Fishery merupakan sebah program pemberdayaan masyarakat pesisir Dusun Cemara, Lembar Selatan, Lombok Barat berbasis ekonomi kreatif dan pengaplikasisan digital marketing dengan memanfaatkan potensi lokal dari desa tersebut. Potensi yang dimanfaatkan disini merupakan hamparan hutan Mangrove yang tumbuh di sepanjang pesisir pantai desa Paremas. Mangrove tersebut akan dimanfaatkan oleh masyarakat setempat dengan konsep ekonomi atau industri kreatif, mengolah beberapa bagian dari mangrove seperti, buah dapat dimanfaatkan menjadi tepung untuk mebuat bolu dan kue sirup dan dodol bernilai gizi. Selain itu bentuk pemanfaatan lain dari hutan mangrove yaitu budidaya kepiting bakau dengan teknik silvofishery.

Oleh karena itu, perlu diadakan inovasi dalam pemberian edukasi atau pembekalan terhadap masyarakat setempat yang dikemas dalam program ekonomi kreatif berkelanjutan terkait sektor perikanan khususnya potensi ekosisem Mangrove melalui program "EKOFISH: Edukasi Optimalisasi Pemanfaatan Ekosistem Mangrove Kepada Masyarakat Dusun Cemara, Lombok Barat". 


\section{ANALISIS PERMASALAHAN}

Dusun Cemara merupakan salah satu dusun di Kecamatan lembar, Lombok Barat yang masuk dalam wilayah pesisr dengan jumlah penduduk lebih dari 1000 jiwa. Berdasarkan keadaan ekonominya, Dusun Cemara dapat dikategorikan sebagai daerah dengan kantong kemiskin struktual yang potensial. Keberadaan hutan bakau (managrove) dengan luasan skitar 66,41 Ha disekitar pesisir pantai merupakan potensi yang masih perlu dioptialkan pemanfaatannya oleh masyarakat. Sejauh ini pemanfaatan mangrove di Dusun Cemara hanya sebagai dareah Ekowisata dan Pematang tambak nelayan. Padahal, jika ditelisik lebih jauh kebermanfaatan hutan mangrove dapat dimanfaatkan lebih dari itu, baik dari segi ekonomi maupul Lingkungn.

Tingkat pendidikan masyarakat yang sangat rendah mengakibatkan kurangnya pengetahuan masyarakat tentang pentingnya ekosistem mangrove bak untuk lingkungan maupun untuk masyarakat itu sendiri.

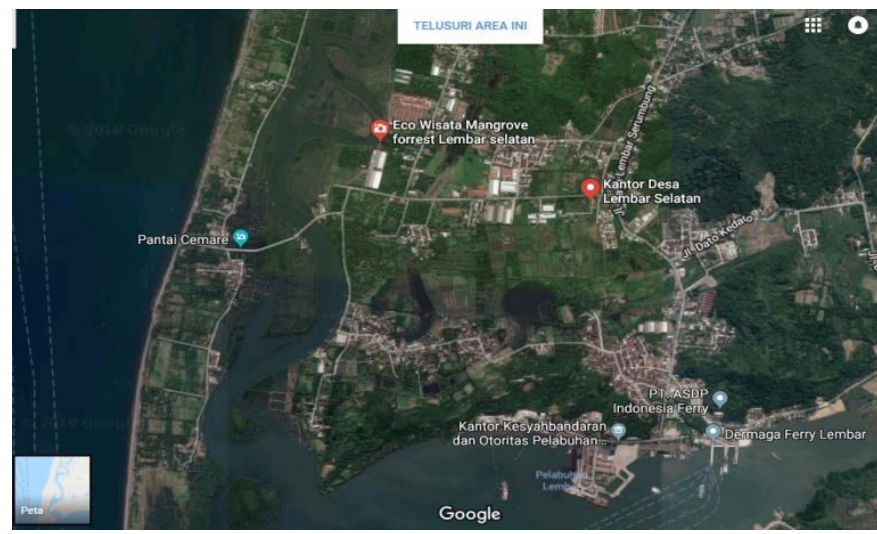

Gambar 1. Peta Lokasi Daerah Sasaran, Dusun Cemara (www.google.co.id)

\section{SOLUSI YANG DITAWARKAN}

Adapun solusi yang kami tawarkan untuk menyelesaikan masalah dari masyarakat Dusun cemra tersebut adalah dengan mengadakan edukasi dan pelatihan optimalisasi fungsi mangrove bagi masyarakat setempat sehingga mampu meningkatkan kualitas masyarak dusun Cemara, Lembar Sleatan.

\section{Observasi Daerah Sasaran}

Obervasi daerah sasaran dilakukan di Dusun Cemara, Desa LembarSelatan, Lombok Barat. Obervasi bertujuan untuk mengenal lebih jauh kebutuhan dan karakteristik masyarakat setempat dan permasalahan yang dihadapi . Diharapkan dengan dilakukan nya obervasi program yang direncanakan menjadi tepat guna dan tepat sasaran.

\section{Izin Pelaksanaan Program}

Setelah proses observasi daerah sasaran, tahapan selanjutnya adalah permohonan izin dan kerjasama sebagai mitra program Ekofish di Dusun Cemara, Desa Lembar Selatan dalam program ini. Dengan adanya mitra yang berkomitmen mendukung program EKOFISH diharapkan program dapat berjalan sesuai rencana. 


\section{Sosialisasi Program}

Sosialisasi dilakukan untuk memperkenalka pada masyarakat Dusun Cemara terhadap program Ekofish ini. Sosialisasi ini memapatkan bahwa akan diadakan kegiatan pelatihan pembuatan produk pangan maupun non pangan dari potensi ekosistem mangrove yang ada di dusun Cemara, selain itu juga ada pelatihan pembuatan dan managemen tambak kepiting bakau dengan teknologi Silvofishery kepada masyarakat setempat sebagai solusi untuk meningkatkan kemandirian mereka dengan memanfaatkan potensi lokal. Sosialisasi ini juga bertujan untuk membentuk Kelompok Swadaya Masyarakat sebagai mitra yang bertanggung jawab terhadap pengembangan program EKOFISH di Dusun Cemara.

\section{Pelatihan Program EKOFISH}

\section{a. Pembutan Poduk olahan Mangrove}

Pelatihan Pembuatan Produk Ekofish dipimpin oleh pemateri yang nantinya mengajarkan langsung kepada masyarakat dalam pembuatan beberapa jenis produk baik pangan seperti Chips, Bolu, Sirup, Dodol, dan Tepung dari buah mangrove, ada juga produk non pangan seperti pembuatan pewarna kain, dan samphoo dari buah dan daun Mangrove menggunakan alat dan bahan yang telah disediakan. Pelatihan dilaksanakan secara berlanjut bukan hanya sehari dengan teknik pendampingan disetiap pembuatannya. Selain pembuatan produk, akan diajarkan pula bagaimna teknik packegibg yang baik dan menarik.
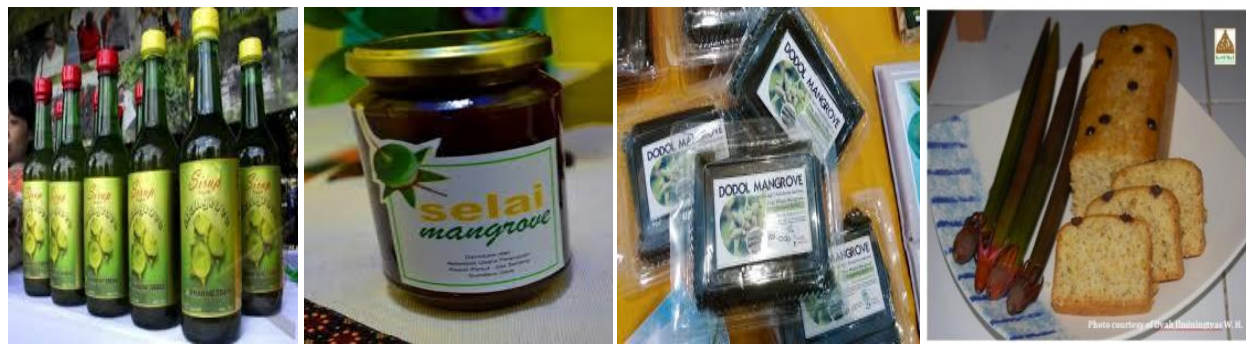

Gambar 2. Contoh Produk Pemanfaatan Buah Mangrove (Www.Google.co.id)

\section{b. Pembutan dan Managemen Tambak Silvofishey}

Pada pelatihan ini lebih fokus ke kelompok bapak-bapak, disini akan ditunjukan bagaimna membuat pematang yang baik tampa menebang dan merusak ekosistem Mangrove, memonitoring pekembangan kepiting terutama saat fase molting, pemberian pakan, hingga manajemen pasca panen.

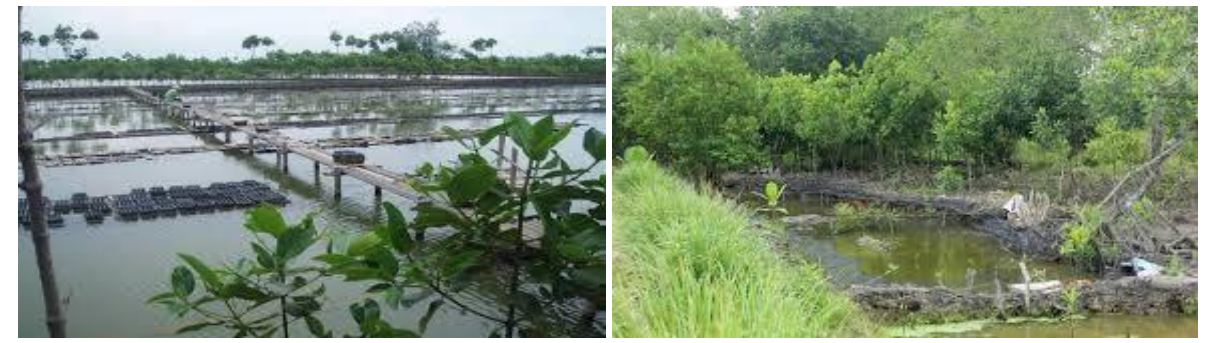

Gambar 3. Contoh Penerapan Tambak Silvofishery (www.Google.co.id) 


\section{a. Pelatihan Digital Marketing}

Untuk mengoptimalkan hasil produk dari program EKOFISH ini, memerlukan teknik pemasaran yang menjang kau pasar lebih luas. Digital marketing adalah kegiatan promosi dan pencarian pasar melalui media digital secara online dengan memanfaatkan berbagai sarana misalnya jejaring sosial. Digital marketing dapat menjangkau seluruh masyarakat di manapun mereka berada tanpa ada lagi batasan geografis ataupun waktu. Dengan kondisi daerah yang masih sanggup di menjangkau signal penuh, masyarakat Cemara dapat dilatih kemampuan pemasarannya dalam media digital.

\section{Pembentukan Kelopok Ekofish sebagai mitra program}

Mitra program yaitu Kelompok Ekofish bertangungjawab terhadap pengembangan dan keberlanjutan program Ekofish. Kelompok Ekofish yang dibentuk diharapkan mampu megembangkan program.

\section{HASIL DAN PEMBAHASAN}

Selama proses pelaksanaannya, program pengabdian EKOFISH ini telah mendapatkan hasil yang cukup sesuai target, yaitu seperti masyarakat disana sudah berhasil membuat produk hasil dari pengolahan buah Mangrove setelah dilakukan dua kali proses pelathan dan edukasi serta 6 kali proses pendampingan. Produk olahan buah mangrove yang mereka hasilkan di berinama ROVEY sebagai merek produk, dengan jenis yang dikembangkan dalah Kue Kering/Cookies atau Choco Chips serta Stik Kastangel. Produk dibuah dari penepungan buah mangrove Soneratia Spp. Yang masih muda dengan cara dikupas kulitnya kemudian dipotong kecil-kecil dan direndam selama 12 jam dalam larutan kapur sirih, setelah direndam buah kemudian dijemur hingga kering dan digilling menjadi tepung. Tepung buah mangrove ini bewarna coklat dengan rasa khas yg sedikit pekat dan berserat. Tepung ini nantinya dijadikan bahan pendamping tepung terigu untuk membuat kue/Cookies.
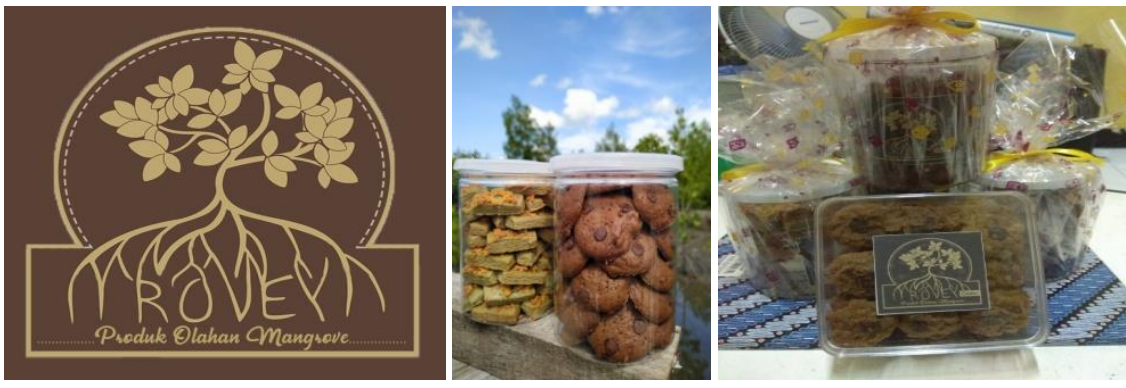

Gambar 4. Produk ROVEY (Sumber:Pribadi)

Cookies juga dapat bersifat fungsional bila di dalam proses pembuatanya ditambahkan bahan yang mempunyai aktifitas fisiologis dengan memberikan efek positif bagi kesehatan tubuh, misalnya cookies yang diperkaya dengan serat, kalsium atau provitamin A ( Muchtadi dan Wijaya, 1996 ). Cookies terbuat dari bahan dasar tepung terigu yang dicampur dengan bahan-bahan lain. Tepung terigu merupakan bubuk halus berasal dari biji gandum. Sampai saat ini, Negara kita masih mengimport bahan baku gandum dari luar negeri. Untuk mengurangi ketergantungan pada tepung terigu, maka perlu dilakukan terobosan baru dengan alternatif tepung lain selain tepung terigu . Salah satu alternatif baru adalah dengan penggunaan tepung ampas magrove (Sonneratia caseolaris)

Pemanfaatan buah mangrove ( Sonneratia caseolaris ) menjadi tepung belum mendapat perhatian di kalangan masyarakat umum termasuk juga tepung ampas mangrove, oleh karena itu pemanfaatan mangrove jenis ini sebagai bahan pangan masih sangat terbatas dan kurang bervariasi. Salah satu variasi produk yang dapat dibuat dari mangrove jenis ini adalah cookies. Pembuatan cookies dari tepung ampas mangrove Sonneratia caseolaris ini merupakan salah satu bentuk inovasi keaneragaman pangan yang mempunyai fungsi ganda dari bahan yang tak mempunyai nilai ekonomis 
menjadi punya nilai jual, sehingga dapat menjadi bahan alternatif untuk penganti bahan pangan yang semakin langka dan mahal, selain itu pula komposisi dalam cookies yang terbuat dari tepung ampas mangrove Sonneratia caseolaris yang dimana salah satu nya terdapat kandungan serat yang dapat menurunkan kadar kolesterol dalam darah dan mengurangi resiko serangan jantung (Sarofa et al, 2016).

Selain produk olahan mangrove dengan merek dagang "ROVEY" yang telah dikembangkan oleh masyarakat Dusun Cemara, hasil dari program EKOFISH juga yaitu masyarakat dapat mengaplikasikan Tambak Budidaya Air Payau dengan tekologi Silvofishery.

Silvofishery atau wanamina adalah sistem pertambakan teknologi tradisional yang menggabungkan antara usaha perikanan dengan penanaman mangrove, yang diikuti konsep pengenalan sistem pengelolaan dengan meminimalkan input dan mengurangi dampak terhadap lingkungan (Macintosh et al, 2002 dalam Pangarevo, dkk., 2014).

Komoditi yang kami aplikasi kan disini sebagai pelatihan awal adalah Budidaya Ikan Nila Salin atau Nila Air Asin. Nila Salin sendiri menjadi pilihan karena memang pengembangnannya masih jarang atau bahkan tidak ada di Lombok, selain itu Ikan nila adalah ikan yang sangat familiar oleh masyarakat khususunya di Lombok yang banyak pembudidaya ikan Nila air tawar. Untuk itu kami disini mengedukasi masyarakat bagaimana memindahkan Ikan nila air tawar tersebut sehingga dapat beradaptasi dengan lingkungan perairan asin atau payau dengan salinitas tertentu.

Cara perlakukannya adalah dengan melakukan tahap Aklimatisasi bertahap atau pembiasan ikan dengan lingkungan baru. Nila air tawar dipelihara dalam bak penampungan terlebih dahulu dalam air yang telah dilakukan pencampuran anatara air asin dan tawar, hari pertama dengan perbandingan 6:1 antara Air tawar dan Asin, selanjutnya setiap harinya ditambahkan 1 air asin, sehingga pada akhirnya komposisi air asin dan air tawar menjadi 1:1. Ikan Nila kemudian dapat dilepas di tambak karena sudah dilatih insang dan alat osmoregulasinya untuk hidup di perairan bersalinitas tinggi.
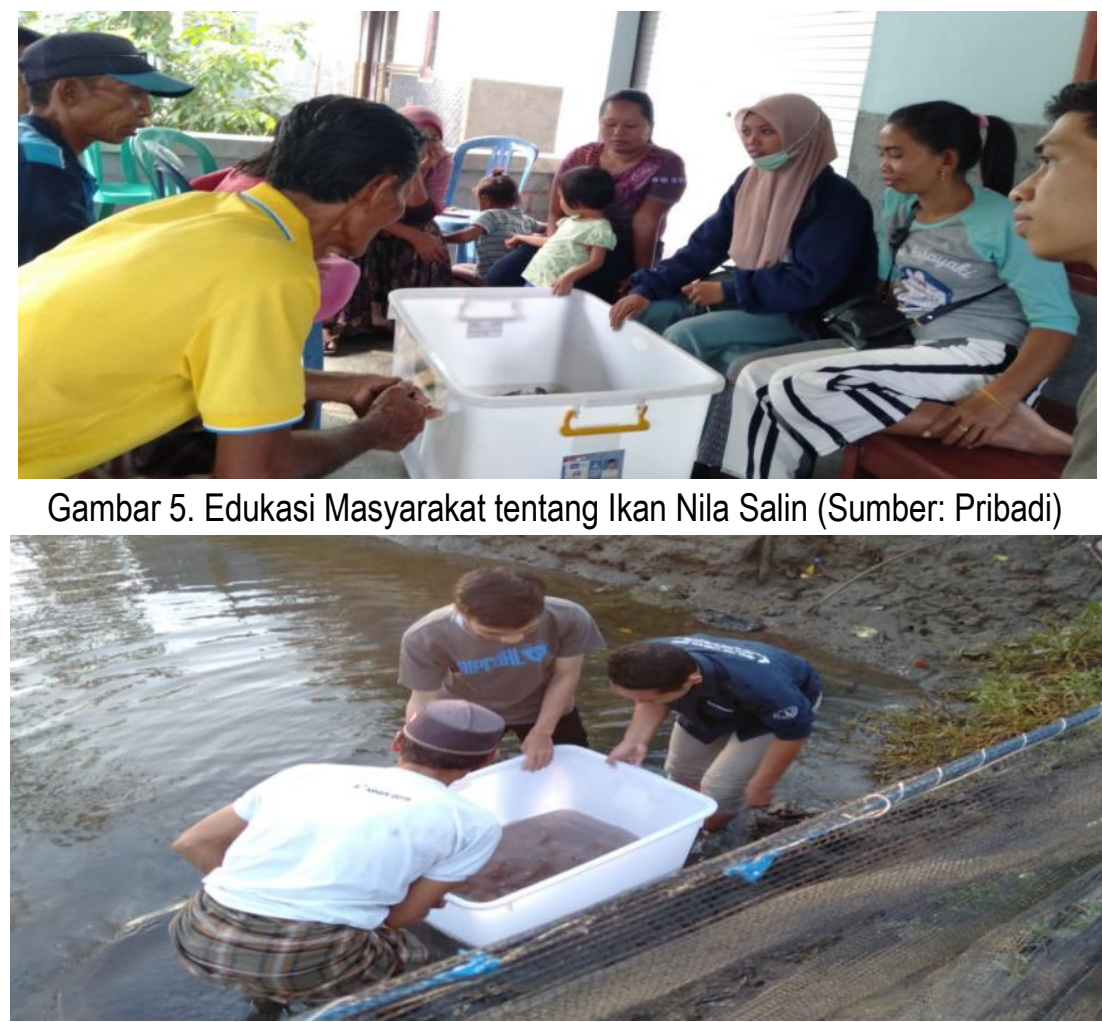

Gambar 6. Pelepasan Ikan Nila yang telah di Alimatisasi (sumber: Pribadi) 


\section{KESIMPULAN}

Adapun kesimpulan yang dapat ditarik dari penjelasan diatas adalah EKOFISH merupakan program pemberdayaan masyarakat pesisr Dusun Cemara dengan memberikan edukasi dan pelatihan kepada masyarakat tentang manfaat dan fingsi Mangrove secara ekonomi sehingga dapat dimanfaatkan dengan Optimal sehingga nantinya dapat membantu meningkatkan perekonomian masyarat berbasis ekonomi kreatif dengan memanfaatkan hasil dari tumbuhan mangrove (buah) yang dapat dijadikan berbagai jenis jajanan dan pangan serta teknik budidaya air payau dengan Teknologi tambak silvofishery. Program ini, dengan memanfaatkan Hutan Mangrove dipastikan akan terus berkembang dan berkelanjutan.

\section{UCAPAN TERIMA KASIH}

Segala puji senantiasa penulis haturkan kehadirat Allah Swt yang telah melimpahkan rahmat dan Hidayah-Nya sehingga penulis dapat melaksanakan menyelesaikan program pengabidan dengan judul "Ekofish : Program Edukasi Optimalisasi Pemanfaatan Ekosistem Mangrove Kepada Masyarakat Dusun Cemara, Lombok Barat". Dalam pelaksanaan program ini tidak akan lepas dari adanya bantuan, bimbingan dan nasihat dari semua pihak, oleh karena itu perkenankanlah penulis menyampaikan terima kasih kepada: 1. Pemerintah Kemenristek Dikti yang telah memberikan kami pendanaan program sehingga kami berkesempatan untuk belajar dan mengabdi langsng kepada masyarakat; 2 . Jajaran pimpinan Universitas Mataram yang telah memberikan kesempatan kepada para mahasiswanya; 3. Ayah dan ibu yang selalu memberi dukungan materi dan spirit dalam menjalani pendidikan di UNRAM ini; 4. Dr. Ir. Sitti Hilyana, M.Si. yang telah membimbing dalam program pengabidan ini; 5 . Bapak Kepala Dusun Cemara yang telah memberikan kami perizinan pelaksanaan program; 6 . Semua Mitra kami dalam hal ini Masyarakat Dusun Cemara yang selama 3 bulan telah bekerjasama dengan baik dalam Program. Semoga apa yang kami lakukan inii dapat memberi manfaat dan dapat diaplikasi kan dengan lebih baik lagi oleh orang-orang diluar sana, didaerah mereka masing-masing. bagi pembaca pada khususnya, masyarakat pada umumnya dan sebagai sumbangsih untuk bangsa.

\section{REFERENSI}

Boedhisantoso, S. 1999. Komunitas Lokal di Kawasan Pesisir dan Pemberdayaannya. Makalah Lokakarya Pembangunan Pranata Sosial Komunitas pesisir. Depok 30 Mei - 1 juni 1999.

Fatmasari, D. 2016. Analisis Sosial Ekonomi dan Budaya masyarakat pesisir Desawaruduwur, Kecamatan Mundu, Kabupaten Cirebon.

Jaya, C. C. (2017). Hubungan Pengetahuan Nilai Budaya Dengan Perilaku Sanitasi Lingkungan (Studi Komparasi Masyarakat Pesisir Etnis Bugis dan Etnis Lampung Pada Kelurahan Kota Karang Kecamatan Teluk Betung Timur Kota Bandarlampung). Hal 25.

Kecamatan Paiton Kabupaten Probolinggo Berbasis Android. Prosiding SENTIA, Vol.8, 2016.

Kementerian Keuangan Republik Indonesia. 2017. Buku Pintar Dana Desa.

Lewaherilla, N. E. 2002. Pariwisata bahari; pemanfaatan potensi wilayah pesisir dan lautan. Makalah Falsafah Sains, 702.

Sri Haryono, Tri Joko. 2005. "Strategi Kelangsungan Hidup Nelayan: Studi tentang diversifikasi pekerjaan keluarga nelayan sebagai salah satu strategi dalam mempertahankan kelangsungan hidup" dalam Jurnal IImiah Kependudukan Vol. 7, No. 2, Juli Desember 2005. Surabaya: Lembaga Penelitian dan Pengabdian Kepada Masyarakat Universitas Airlangga.

Supriadi, A.; M.N. Fadli; K. Malik. 2016. Membangun Sistem Smart Village untuk Menciptakan Ekonomi Masyarakat Desa Mandiri di Desa Alastengah.

Suprijanto, I. 2006. Karakteristik Spesifik, Permasalahan dan Potensi Pengembangan Kawasan Kota Tepi Laut. Pantai (Coastal City) di Indonesia. 
Sylvi, P.A.Y. 2018. Kompasiana. "Membangun Indonesia dari Pinggiran Melalui Smart Village". telah diakses pada tanggal 5 Mei 2018 pukul 16.35 WITA https://www.kompasiana.com/pkdodlanri/5a992c7edd0fa859045db843/membangun-indonesia-daripinggiran-melalui-smart-village.

Undang-Undang Republik Indonesia Nomor 6 tahun 2014 tentang Desa.

Usman, U. 2017. Dinamika Politik Sepuluh Tahun Perdamaian Di Aceh (Analisis Politik Kawasan Pesisir Timur Aceh). Jurnal Humaniora, 1(1), 50-60.

Zamzami, L. 2011. Pemberdayaan Ekonomi Masyarakat Pesisir di Nagari Ampiang Perak, Sumatera Barat. MIMBAR, Vol. 27, No. 1: 113-125. 